\title{
IGF-I and insulin induce different intracellular calcium signals in skeletal muscle cells
}

\author{
A Espinosa, M Estrada and E Jaimovich \\ Centro de Estudios Moleculares de la Célula Insitiuto de Ciencas Biomédicas Facultad de Medicina Universidad de Chile, Independencia 1027, \\ Santiago 7, Chile \\ (Requests for offprints should be addressed to E Jaimovich; Email: ejaimovi@med.uchile.cl)
}

\begin{abstract}
We studied the effect of IGF-I and insulin on intracellular $\mathrm{Ca}^{2+}$ in primary cultured myotubes. IGF-I induced a fast and transient $\mathrm{Ca}^{2+}$ increase, measured as fluo-3 fluorescence. This response was blocked by both genistein and AG538. IGF-I induced a fast inositol-1,4,5-trisphosphate $\left(\mathrm{IP}_{3}\right)$ increase, kinetically similar to the $\mathrm{Ca}^{2+}$ rise. The $\mathrm{Ca}^{2+}$ signal was blocked by inhibitors of the $\mathrm{IP}_{3}$ pathway. On the other hand, insulin produced a fast $(<1 \mathrm{~s})$ and transient $\mathrm{Ca}^{2+}$ increase. Insulin-induced $\mathrm{Ca}^{2+}$ increase was blocked in $\mathrm{Ca}^{2+}$-free medium and by either nifedipine or ryanodine. In the normal muscle NLT cell line, the $\mathrm{Ca}^{2+}$ signals induced by both hormones resemble those of primary myotubes. GLT cells, lacking the $\alpha 1$-subunit of
\end{abstract}

dihydropyridine receptor (DHPR), responded to IGF-I but not to insulin, while GLT cells transfected with the $\alpha 1$-subunit of DHPR reacted to both hormones. Moreover, dyspedic muscle cells, lacking ryanodine receptors, responded to IGF-I as NLT cells, however they show no insulin-induced calcium increase. Moreover, G-protein inhibitors, pertussis toxin (PTX) and GDP $\beta S$, blocked the insulin-induced $\mathrm{Ca}^{2+}$ increase without major modification of the response to IGF-I. The different intracellular $\mathrm{Ca}^{2+}$ patterns produced by IGF-I and insulin may improve our understanding of the early action mechanisms for these hormones in skeletal muscle cells.

Journal of Endocrinology (2004) 182, 339-351

\section{Introduction}

Skeletal muscle is a target tissue for the action of both insulin-like growth factor I (IGF-I) and insulin (Adams 2002, Kimball et al. 2002). Some of the intracellular signaling pathways activated by these hormones are similar; however, the global effects in muscle cells are different (Crown et al. 2000). IGF-I regulates several adaptive processes in skeletal muscle such as growth (Coolican et al. 1997), differentiation (Tureckova et al. 2001) and hypertrophy (Semsarian et al. 1999) while insulin, whose receptors have a similar heterotetrameric structure to those of the IGF-I receptor, is involved in metabolic processes including glucose transporter (GLUT)-4 translocation (Ryder et al. 2001) and protein synthesis (Kimball et al. 2002). Moreover, IGF-I and insulin receptors are composed of two $\alpha$ - and two $\beta$-subunits and share $80 \%$ structural homology in their $\beta$-subunits. The binding of IGF-I or insulin to its receptors promotes dimerization of receptors and tyrosine autophosphorylation. This event produces the subsequent phosphorylation of proteins such as insulin receptor substrate 1 (IRS-1) and docking of proteins that contain Src homology (Shc) (Blakesley et al. 1996, Kaburagi et al. 1999). On the other hand, recent evidence indicates that IGF-I and insulin receptors require a heterotrimeric G-protein for some of their biological effects (Kanoh et al.
2002). Imamura et al. (1999) have described in adipocytes that $\mathrm{G}$-protein $\mathrm{G} \alpha \mathrm{q} / 11$ associates with the insulin receptor to cause phosphatidylinositol 3-kinase (PI3K) signals, producing GLUT-4 translocation (Imamura et al. 1999). Moreover in intestinal smooth muscle, IGF-I mediates mitogen-activated protein kinase (MAPK) activation through a pathway that is, at least in part, Gai dependent and promotes cell growth (Kuemmerle \& Murthy 2001). The signal transduction mechanisms responsible for the differential effects of these two hormones and their receptor-mediated pathways are poorly understood. A pathway of divergence for the effects of these hormones could be the generation of different patterns of calcium signals and, consequently, differential activation of $\mathrm{Ca}^{2+}$-dependent pathways by either IGF-I or insulin. In skeletal muscle cells $\mathrm{Ca}^{2+}$ regulates contractile activity as well as different energetic pathways (Dulhunty et al. 2002). In several cell models, IGF-I binds to a receptor (IGF-IR) with intrinsic tyrosine kinase activity and activates several substrates; an example is phospholipase $\mathrm{C}-\gamma$ (PLC- $\gamma$ ), regulating cardiac muscle differentiation (Hong et al. 2001). Activation of PLC through IGF-I generates inositol-1,4,5-trisphosphate $\left(\mathrm{IP}_{3}\right)$ and produces $\mathrm{Ca}^{2+}$ release from endoplasmic reticulum (Takasu et al. 1989, Guse et al. 1992). Furthermore, IGF-I may elicit $\mathrm{Ca}^{2+}$ influx from the extracellular medium by a variety of mechanisms, which seem to depend on the cell 
type (Delbono et al. 1997, Solem \& Thomas 1998). In fresh mouse muscle fibers, insulin increases calcium concentration in the cytoplasm located near the plasma membrane through the entry of calcium from outside the cell rather than release from the sarcoplasmic reticulum (Bruton et al. 2001). The interplay between $\mathrm{Ca}^{2+}$ release from $\mathrm{IP}_{3}-$ sensitive stores and $\mathrm{Ca}^{2+}$ influx through the plasma membrane may result in a variety of $\mathrm{Ca}^{2+}$ signals, which can be important for differential generation of patterns of calcium transients and also in the interaction between different $\mathrm{Ca}^{2+}$-dependent pathways (Foskett et al. 1991).

In skeletal muscle cells, calcium has been mainly associated with excitation-contraction coupling (Dulhunty et al. 2002); nevertheless in our laboratory we have described a role for $\mathrm{Ca}^{2+}$ as second messenger in the activation of MAPK, transcription factors and induction of early genes (Carrasco et al. 2003). Some hormones induce intracellular $\mathrm{Ca}^{2+}$ increases in muscle cells independently of contraction, by a mechanism mediated by $\mathrm{IP}_{3}-$ dependent $\mathrm{Ca}^{2+}$ release from intracellular stores (Estrada et al. 2000, 2003). The slow $\mathrm{Ca}^{2+}$ signal related to regulation of gene expression can be activated by membrane depolarization and has been shown to involve the voltage sensor, dihydropyridine receptor (DHPR) (Araya et al. 2003). IGF-I has been shown to produce activation of voltage-gated $\mathrm{Ca}^{2+}$ channels and to produce $\mathrm{Ca}^{2+}$ entry in chondrocytes (Poiraudeau et al. 1997) and cardiomyocytes (Solem \& Thomas 1998); IP ${ }_{3}$-dependent $\mathrm{Ca}^{2+}$ release has recently been described in cardiomyocytes in response to IGF-I (Ibarra et al. 2003). Moreover Delbono et al. (1997) have shown a modulation by IGF-I of both activity of DHPR and an increase in the number of DHPRs expressed in transgenic mice that overexpress human IGF-I (Renganathan et al. 1997). A detailed study of $\mathrm{Ca}^{2+}$ signals induced by IGF-I and insulin in skeletal muscle cells has not been reported. In the present study, we investigated the effects produced by both IGF-I and insulin on intracellular $\mathrm{Ca}^{2+}$ changes in skeletal muscle cells and we explored the mechanisms involved in these responses. We focused our study on the kinetics of the $\mathrm{Ca}^{2+}$ signals and on the $\mathrm{Ca}^{2+}$ release mechanisms involved. Moreover, we evaluated the $\mathrm{Ca}^{2+}$ signals induced by both hormones in different cell lines: NLT, from normal skeletal muscle cells; GLT, dysgenic cell line lacking the $\alpha 1$-subunit of the DHPR (Powell et al. 1996); GLT cells transfected with the a1-subunit of DHPR; and 1B5, dyspedic cells lacking all three subtypes of ryanodine receptor (RyR). Our results show that IGF-I and insulin use different signaling pathways to elicit $\mathrm{Ca}^{2+}$ signals in skeletal muscle cells.

\section{Material and Methods}

\section{Chemical reagents}

IGF-I and insulin (recombinant human) were purchased from Invitrogen. U73122, ryanodine, nifedipine and verapamil were purchased from Sigma. Fluo-3 acetoxymethylester (fluo-3 AM) was purchased from Molecular Probes (Eugene, OR, USA). Bordetella pertussis toxin (PTX), GDP $\beta S$, AG538, genistein and xestospongin C were from Calbiochem (La Jolla, CA, USA). Anti-IGF-I receptor against $\beta$-subunit and anti-insulin receptor antibodies were obtained from Santa Cruz Biotechnology Inc. (Santa Cruz, CA, USA). Enhanced chemiluminescence reagents and horseradish peroxidase-linked antirabbit immunoglobulin G (IgG) were obtained from Pierce Chemical Co. (Rockford, IL, USA). Other reagents were of analytical grade.

\section{Primary cell cultures}

Rat myotubes kept in primary culture were used for measurement of intracellular calcium levels as described previously (Jaimovich et al. 2000, Estrada et al. 2003). Briefly, skeletal muscle tissue from hindlimbs was isolated from rats aged 12-24 h. After dissection, the tissue was mechanically dispersed and then treated with $0 \cdot 2 \%(\mathrm{w} / \mathrm{v})$ collagenase for $30 \mathrm{~min}$, at $37^{\circ} \mathrm{C}$, under mild agitation. The dissociated tissue was filtered through lens tissue paper and spun down at low speed. Cells were plated onto either gelatin-coated glass coverslips at a density of $350 \times 10^{3}$ cells per dish $(35 \mathrm{~mm})$ for cytosolic calcium fluorescence measurements or at a density of $9.5 \times 10^{5}$ cells onto gelatin-coated plates $(60 \mathrm{~mm})$ for $\mathrm{IP}_{3}$ radioreceptor assay determination. Culture medium was Dulbecco's modified Eagle's medium (DMEM)/F12, 10\% bovine serum, 2.5\% fetal calf serum, $100 \mathrm{mg} / 1$ penicillin, $50 \mathrm{mg} / 1$ streptomycin and $2.5 \mathrm{mg} / 1$ amphotericin B. The medium was then replaced by a medium without serum. Myotubes with an estimated purity of more than $90 \%$ were visible after the fifth day of culture. Unless indicated, we used 6to 8-day-old cultures exhibiting a fairly homogeneous population of myotubes with large central nuclei and measuring 200-300 $\mu \mathrm{m}$ long and 20-40 $\mu \mathrm{m}$ wide, corresponding to young, not fully differentiated cells. Such cells allowed us to obtain proportionally large signals from the nuclei. Myotubes used for calcium signal measurements did not spontaneously contract or exhibit spontaneous calcium transients.

\section{Cell lines}

We used the mutant mouse cell line GLT (muscular dysGenic, $m d g / m d g$, line transfected with the Large $\mathrm{T}$ antigen), and the wild-type cell line NLT, prepared from dysgenic and normal cultures respectively. GLT $\alpha 1$ corresponds to GLT cells transfected with the $\alpha 1$-subunit DNA of skeletal DHPR as described by Powell et al. (2001). Myoblasts of the immortalized dyspedic cell line 1B5 (Moore et al. 1998), kindly provided by Dr Paul Allen (Women and Children Hospital, Boston, MA, USA), were used to determine the role of RyRs in the calcium 
responses to hormones. All muscle cell lines were cultivated in DMEM (1 g of glucose/1), $2 \cdot 5 \%$ heat-inactivated fetal calf serum and $10 \%$ bovine serum (all Life Technologies) in gelatin-covered dishes at $37^{\circ} \mathrm{C}$ in $5 \%$ $\mathrm{CO}_{2}$. The serum was reduced to $2 \%$ horse serum after 2 days to induce cell maturation and fusion, and cells were studied 5-7 days after differentiation was initiated.

\section{Intracellular calcium signals at single-cell level}

For intracellular calcium measurements, myotubes were cultured on glass coverslips until they reached $80 \%$ confluence. Calcium images were obtained from noncontracting myotubes pre-loaded with the fluorescence $\mathrm{Ca}^{2+}$ dye fluo-3 AM (Molecular Probes), using either an inverted confocal microscope (Carl Zeiss Axiovert 135 M-LSM Microsystems), or a fluorescence microscope (Olympus Diaphot-TMD, Nikon Corporation), equipped with a cooled charge-coupled device camera and image acquisition system (Spectra Source MCD 600). Myotubes were washed three times with Krebs buffer $(145 \mathrm{mM}$ $\mathrm{NaCl}, 5 \mathrm{mM} \mathrm{KCl}, 2 \cdot 6 \mathrm{mM} \mathrm{CaCl}, 1 \mathrm{mM} \mathrm{MgCl}, 10 \mathrm{mM}$ Hepes- $\mathrm{Na}, 5.6 \mathrm{mM}$ glucose, $\mathrm{pH} 7 \cdot 4$ ), to remove serum, and loaded with $5 \cdot 4 \mu \mathrm{M}$ fluo-3 AM (coming from a stock in $20 \%$ pluronic acid-dimethyl sulfoxide), for $30 \mathrm{~min}$ at room temperature. After loading, myotubes were washed for $10 \mathrm{~min}$ to allow de-esterification of the dye, and were used within $2 \mathrm{~h}$. The cell-containing coverslips were mounted in a $1 \mathrm{ml}$ capacity plastic chamber and placed in the microscope for fluorescence measurements after excitation with a $488 \mathrm{~nm}$ wavelength argon laser beam or filter system. Time series of images were recorded before and after cell stimulation; 80-100 images were recorded for each experiment, each series containing images recorded at time intervals of $1-2 \mathrm{~s}$ and analyzed frame by frame with the image data acquisition program (Spectra-Source) of the equipment. A PlanApo $\times 60$ (numerical aperture 1.4) objective lens was generally used. In most of the acquisitions, the image dimension was $512 \times 120$ pixels. The inhibitors were added during the dye incubation, times and concentrations are indicated in the Results. To assess the role of G-proteins, myotubes were incubated with either $1 \mu \mathrm{g} / \mathrm{mL}$ PTX for $5 \mathrm{~h}$, or in a permeabilization solution $(100 \mathrm{mM} \mathrm{KCl}, 20 \mathrm{mM} \mathrm{NaCl}$, $5 \mathrm{mM} \mathrm{MgSO}, 1 \mathrm{mM} \mathrm{NaH} \mathrm{PO}_{4}, 25 \mathrm{mM} \mathrm{NaHCO}$, $3 \mathrm{mM}$ EGTA, $1 \mathrm{mM} \mathrm{CaCl}$, $20 \mathrm{mM}$ Tris-- $\mathrm{HCl}(\mathrm{pH} \mathrm{7} \cdot 4)$, $0 \cdot 1 \%$ BSA, $1 \mathrm{mM}$ ATP, $0 \cdot 1 \%$ glucose and $40 \mathrm{mg} / \mathrm{ml}$ saponin), for $5 \mathrm{~min}$ in the presence or absence of $100 \mathrm{nM}$ GDP $\beta S$, a non-hydrolysable analog of GDP, before hormone stimulation. Intracellular $\mathrm{Ca}^{2+}$ was expressed as a percentage of fluorescence intensity relative to basal fluorescence (a value stable for at least $5 \mathrm{~min}$ in resting conditions). The fluorescence intensity increase is proportional to the rise in intracellular $\mathrm{Ca}^{2+}$ level (Minta et al. 1989).
Measurements of $\mathrm{IP}_{3}$ mass

Myotubes were rinsed and pre-incubated at room temperature for $20 \mathrm{~min}$ with a saline solution of the following composition: $145 \mathrm{mM} \mathrm{NaCl}, 5 \mathrm{mM} \mathrm{KCl}, 2.6 \mathrm{mM} \mathrm{CaCl}_{2}$, $1 \mathrm{mM} \mathrm{MgCl} 2,10 \mathrm{mM}$ Hepes-Na, $5.6 \mathrm{mM}$ glucose, $\mathrm{pH}$ $7 \cdot 4$. Cells were stimulated by replacing this solution with IGF-I (1-100 nM)-containing solution in the presence or absence of inhibitors. At the times indicated the reaction was stopped by rapid aspiration of the stimulating solution, addition of $0.8 \mathrm{M}$ ice-cold perchloric acid and freezing with liquid nitrogen. Samples were allowed to thaw and cell debris was spun down for protein determination. The supernatant was neutralized with a solution of $2 \mathrm{M} \mathrm{KOH}$, $0 \cdot 1 \mathrm{M}$ 2-N-morpholinoethanesulfonic acid (MES), and $15 \mathrm{mM}$ EDTA. The neutralized extracts were frozen until required for $\mathrm{IP}_{3}$ determination. $\mathrm{IP}_{3}$ mass measurements were carried out by radioreceptor assay (Bredt et al. 1989).

\section{IGF-I and insulin receptor immunodetection}

Homogenate proteins were resolved in 7\% SDSpolyacrylamide electrophoresis gels and transferred to nitrocellulose membranes for $2 \mathrm{~h}$ at $0.4 \mathrm{~A}$. Primary antibody incubations using dilutions of 1:1000 of antibodies against subunit $\beta$, either of IGF-I receptor or insulin receptor (IR), were carried out at $4{ }^{\circ} \mathrm{C}$ overnight. After incubation with horseradish peroxidase-conjugated secondary antibodies for $2 \mathrm{~h}$ at room temperature, the membranes were developed by enhanced chemiluminescence according to the manufacturer's instructions. Membranes were stripped and re-probed with an antibody which detects $\beta$-actin in order to control for protein loading.

\section{Statistics}

All data are expressed as means \pm S.D. Differences between basal and post-stimulated points were determined using a paired Student's $t$-test. $P<0 \cdot 05$ was considered statistically significant.

\section{Results}

\section{Effects of IGF-I on intracellular calcium in myotubes}

Using the fluorescence dye fluo-3 AM, intracellular $\mathrm{Ca}^{2+}$ measurements were performed at the single-cell level in myotubes. In Fig. 1A a representative gallery of fluorescence images acquired at indicated times is shown. IGF-I at concentrations $(10 \mathrm{nM})$ in the physiological range induced a fast and transient $\mathrm{Ca}^{2+}$ increase in myotubes. The fluorescence changes began during the first second after hormone addition with a maximal fluorescence peak at $6 \cdot 3 \pm 1 \cdot 6 \mathrm{~s}$ (range $4-11 \mathrm{~s}, n=39$ cells, from 23 different cultures; Fig. $1 \mathrm{~A}$ and B). The response was transient and fluorescence returned towards basal values 


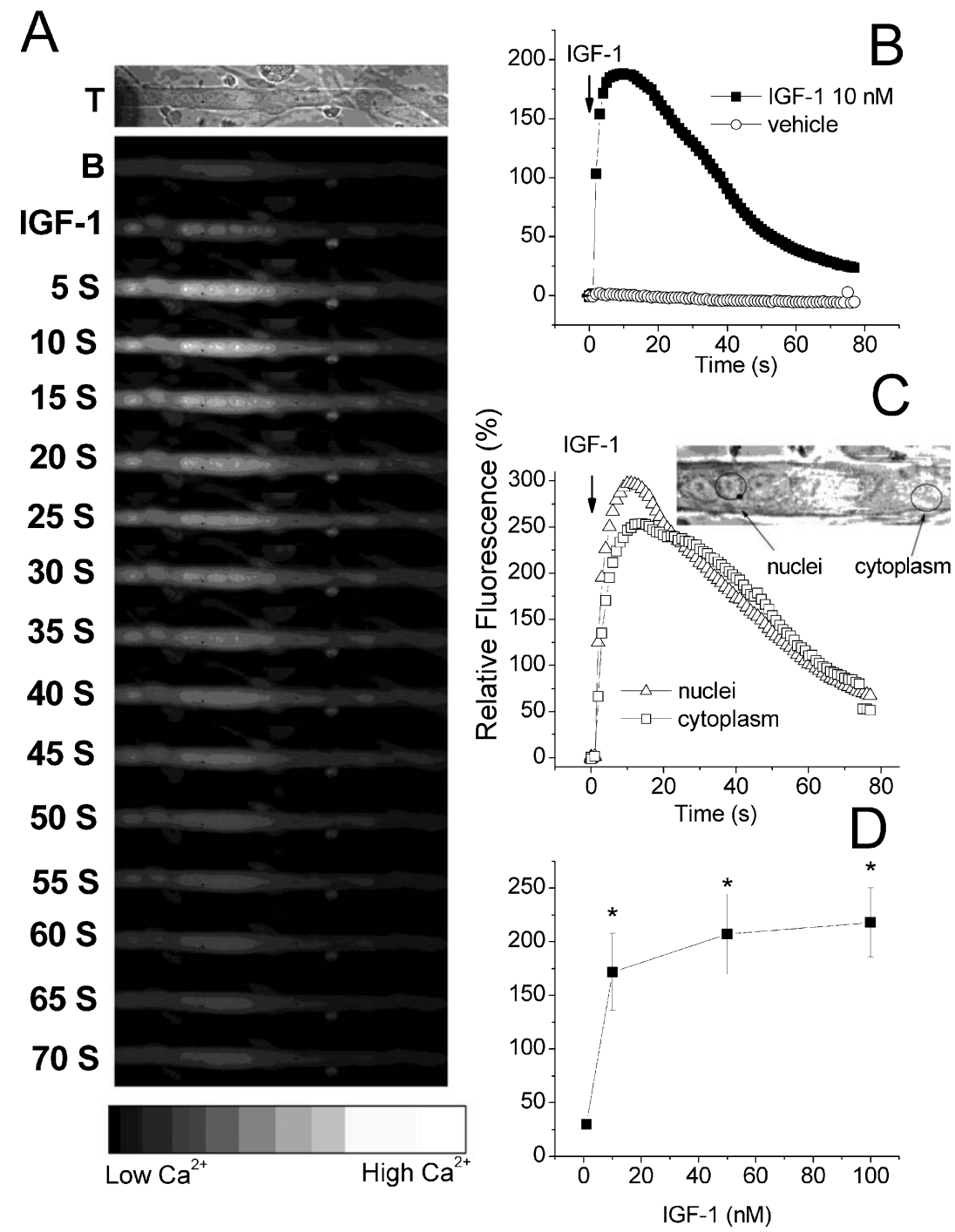

Figure 1 IGF-I induces intracellular calcium increase in myotubes. (A) Series of fluorescence images acquired every $5 \mathrm{~s}$. Cells were incubated for 30 min with fluo-3 AM. $\mathrm{T}$, transmitted image (bright field); $\mathrm{B}$, basal fluorescence at time zero; fluorescence levels are shown at the times indicated after addition of $10 \mathrm{nM}$ IGF-I. Note that during the peak, fluorescence in the nuclei is higher than that of the cytoplasm. (B) Fluorescence time course for a representative experiment $(n=39)$ of myotubes stimulated with either IGF-I (hormone was added at the arrow) or vehicle $(<0 \cdot 01 \%$ acetic acid, $n=5)$ as indicated. (C) Kinetics for $\mathrm{Ca}^{2+}$ increase in regions of interest (ROI) located in either nuclei or cytoplasm as indicated. Inset, transmitted image indicating the position of chosen ROls in the myotube. (D) IGF-I induces a concentration-dependent increase in $\mathrm{Ca}^{2+}$. The graph represents the peak value obtained with concentrations of 1, 10, 50 and $100 \mathrm{nM}$ IGF-I ( $n=3$ for each point, $P<0 \cdot 05$ ).

after $60 \mathrm{~s}$. Calcium increased in the whole myotube, but fluorescence was more intense in the nuclei; we analyzed whether there was any difference in the kinetics of $\mathrm{Ca}^{2+}$ signals between nucleus and cytoplasm. Regions of interest (ROI) were delimited in the cytoplasm and nucleus of the myotube (Fig. 1C, inset) and a sum of all pixels of these areas was performed. ROI analyses show that fluorescence changes elicited by IGF-I began at the same time and reached maximal values simultaneously in both cell compartments (Fig. 1C). A maximal fluorescence increase in myotubes induced by IGF-I was concentration dependent. Increasing concentrations of IGF-I were applied to primary myotubes and the percentage of fluorescence increase referred to basal values was plotted (Fig. 1D). 


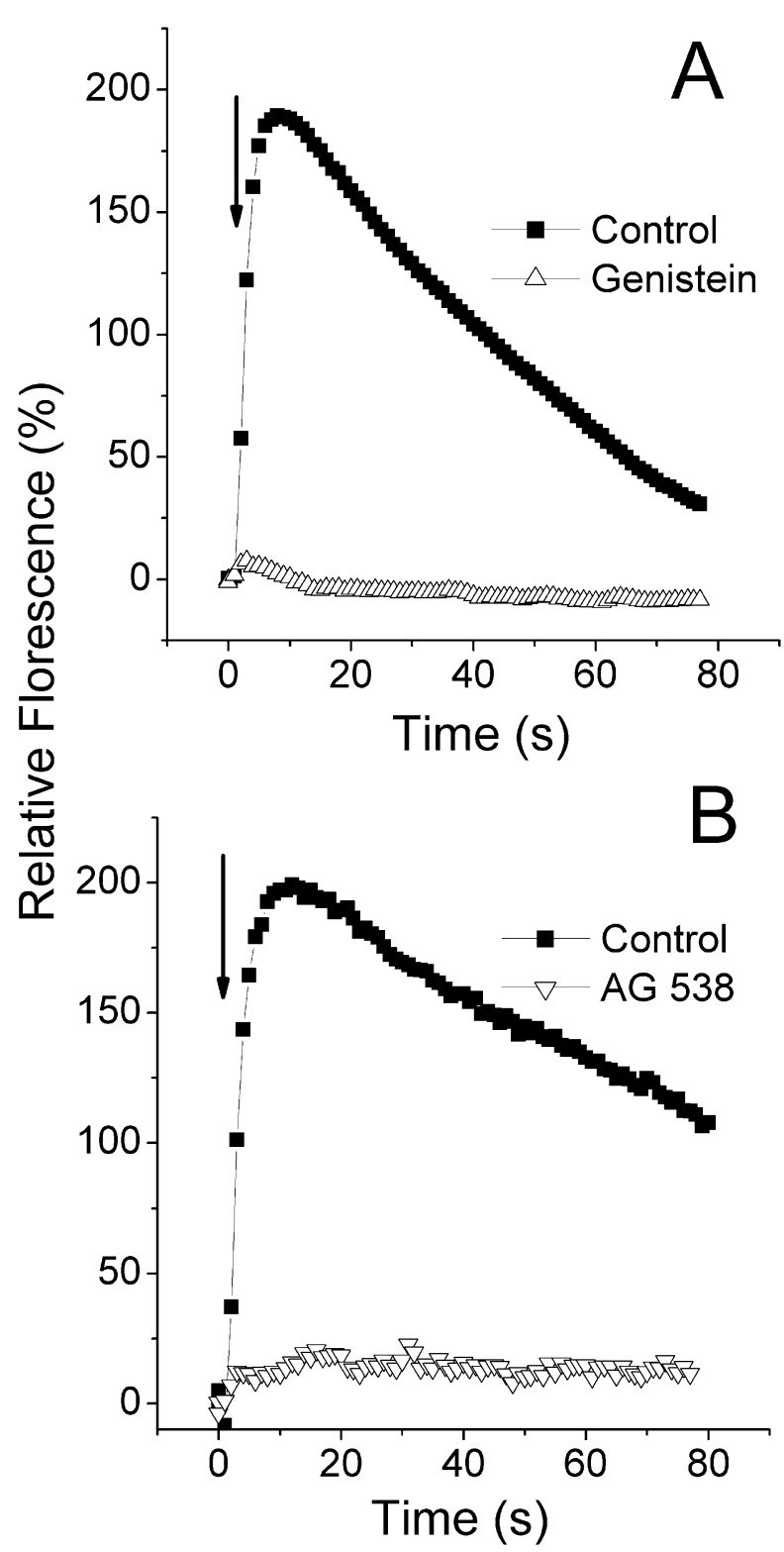

Figure 2 Effect of two inhibitors of tyrosine kinase receptors on calcium increase induced by IGF-I. Myotubes were incubated for 15 min with $100 \mu \mathrm{M}$ genistein (A) or $400 \mathrm{nM}$ AG538 (B), a competitive inhibitor of IGF-I receptors. Both genistein and AG538 blocked the $\mathrm{Ca}^{2+}$ increase induced by IGF-I $(n=9$ and 6 respectively). Control curves represent the effect of $10 \mathrm{nM}$ IGF-I without inhibitors.

In the concentration range studied $(1-100 \mathrm{nM})$ an apparent $K_{\mathrm{d}}$ of $4.4 \mathrm{nM}$ was estimated; $10 \mathrm{nM}$ IGF-I was routinely used in all subsequent experiments.

To determine whether IGF-I receptor activation is involved in the $\mathrm{Ca}^{2+}$ signals induced by IGF-I, we used $100 \mu \mathrm{M}$ genistein, a tyrosine kinase inhibitor (Fig. 2A). Addition of genistein completely blocked IGF-I-induced
$\mathrm{Ca}^{2+}$ increase $(n=9)$. We further tested the effects of AG538, a competitive inhibitor of IGF-I R kinase autophosphorylation (Blum et al. 2000); $400 \mathrm{nM}$ AG538 produced almost complete inhibition of IGF-I-induced $\mathrm{Ca}^{2+}$ increase in the myotubes (Fig. $2 \mathrm{~B} ; n=6$ ). These results indicate that the tyrosine kinase domain of the IGF-I receptor is required to induce IGF-I-stimulated intracellular $\mathrm{Ca}^{2+}$ increases in myotubes.

In order to investigate whether the IGF-I-induced $\mathrm{Ca}^{2+}$ increase was due to $\mathrm{Ca}^{2+}$ influx, two types of experiments were performed. First, myotubes were incubated and stimulated in a nominally $\mathrm{Ca}^{2+}$-free medium (1 mM EGTA added) (Fig. 3A). In these conditions, IGF-I produced an intracellular $\mathrm{Ca}^{2+}$ increase in $78.9 \%$ of myotubes (45 of 57 ); the fluorescence peak was slightly reduced $(8 \cdot 1 \%$ as a mean) and the time to peak was longer $(10 \pm 0.6 \mathrm{~s} ; n=42, P<0.05$ vs $6.3 \pm 1.6 \mathrm{~s})$ in the $\mathrm{Ca}^{2+}$ condition. These results suggest that extracellular $\mathrm{Ca}^{2+}$ has some role in the early part of the $\mathrm{Ca}^{2+}$ signal induced by IGF-I. The second type of experiment was designed to identify whether IGF-I-induced $\mathrm{Ca}^{2+}$ influx was mediated by voltage-gated $\mathrm{Ca}^{2+}$ channels (VGCC). Myotubes were pretreated with nifedipine (Fig. 3B) or verapamil (Fig. 3C), two specific L-type VGCC antagonists. With both antagonists the IGF-I-induced calcium response was both smaller and slower than control. The fluorescence peak value was reached at $16 \pm 3 \cdot 4(n=22)$ and $13 \pm 7 \cdot 5 \mathrm{~s}$ $(n=9)$ respectively.

In order to determine whether $\mathrm{Ca}^{2+}$ is being released from RyRs, we used $20 \mu \mathrm{M}$ ryanodine (Fig. 3D). Treatment of myotubes with ryanodine reduced the IGF-Iinduced $\mathrm{Ca}^{2+}$ spike and produced a delay in time to fluorescence peak, which was similar to that seen with L-type VGCC antagonists (Fig. 3B and C). Nevertheless, the main part of the $\mathrm{Ca}^{2+}$ signal evoked by IGF-I in myotubes was still seen in the presence of the inhibitors. These data together suggest that IGF-I-induced intracellular $\mathrm{Ca}^{2+}$ increase is complex and could be understood as a two-phase response: an early component appears to be blocked by either L-type VGCC antagonists or ryanodine, and a late component appears to be insensitive to these inhibitors.

In many cell types the rapid increase in intracellular $\mathrm{Ca}^{2+}$ levels is associated with $\mathrm{IP}_{3}$ receptors, present in the intracellular $\mathrm{Ca}^{2+}$ stores (Berridge 1995). In myotubes, hormone- and membrane potential-stimulated $\mathrm{Ca}^{2+}$ increases are mediated by activation of $\mathrm{IP}_{3}$ receptors (Jaimovich \& Rojas 1994, Jaimovich et al. 2000, Powell et al. 2001). To test the possible involvement of this pathway in the calcium responses to IGF-I in myotubes, inhibitors of the $\mathrm{IP}_{3}$ pathway were used: $10 \mu \mathrm{M} \mathrm{U} 73122$, a specific inhibitor of PLC, and $5 \mu \mathrm{M}$ xestospongin $\mathrm{C}$, a blocker of $\mathrm{IP}_{3}$ receptors, were tested. Myotubes were pre-incubated with either inhibitor, in medium both with and without $\mathrm{Ca}^{2+}$. With both inhibitors the response was almost completely abolished in $\mathrm{Ca}^{2+}$-free medium 


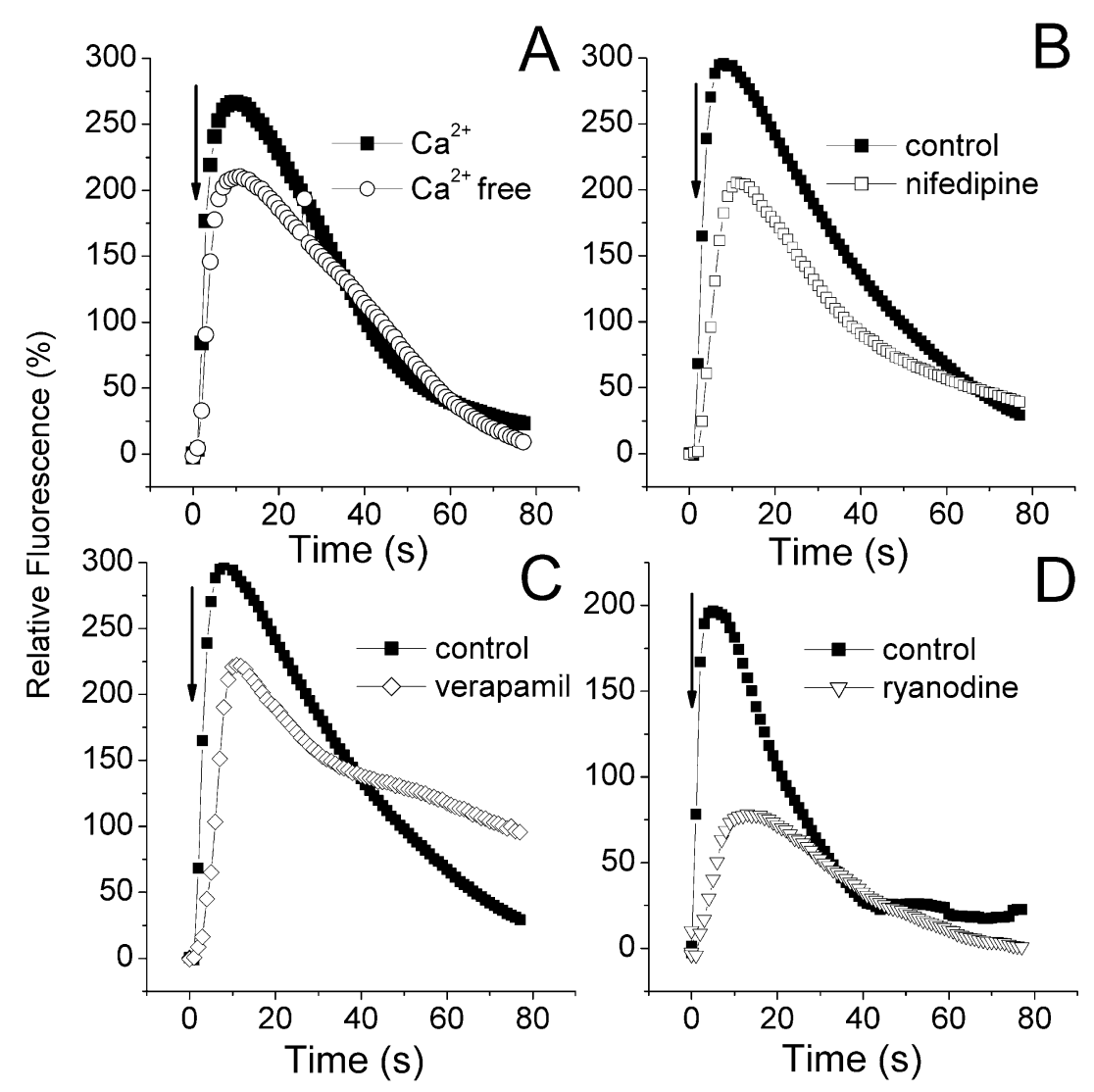

Figure 3 Role of external $\mathrm{Ca}^{2+}$, DHPR and RyR in IGF-I-induced calcium increase. (A) Fluorescence changes after addition (arrow) of $10 \mathrm{nM} \mathrm{IGF-I,} \mathrm{with} \mathrm{either} 2.6 \mathrm{mM} \mathrm{Ca}^{2+}$ or $\mathrm{Ca}^{2+}$-free ( $1 \mathrm{mM}$ EGTA) medium as indicated ( $n=29$ and 35 respectively). Effect of two inhibitors of DHPR. In cells previously incubated with $20 \mu \mathrm{M}$ nifedipine (B) or $20 \mu \mathrm{M}$ verapamil (C), a fast component of the signal induced by IGF-I was inhibited $(n=22$ and 9 respectively). (D) Ryanodine $(20 \mu \mathrm{M})$ produced both slowing and partial reduction of the fluorescence increase $(n=8)$. Each graph illustrates representative kinetics of experiments performed with each inhibitor. Control curves represent the effect of $10 \mathrm{nM}$ IGF-I without inhibitors.

(Fig. 4A and B). Nevertheless in normal $\mathrm{Ca}^{2+}$ IGF-I produced a fast and transient response lower in magnitude and duration than the control without inhibitors (Fig. 4A and $\mathrm{B})$. These experiments suggest that a major, relatively slow component of the IGF-I-induced $\mathrm{Ca}^{2+}$ transient is mediated by $\mathrm{IP}_{3}$. In order to confirm a role for $\mathrm{IP}_{3}$ in this signal, we measured the mass of $\mathrm{IP}_{3}$ in cells after stimulation. The effect of $10 \mathrm{nM}$ IGF-I on the $\mathrm{IP}_{3}$ levels in rat myotubes at different times is depicted in Fig. 4C. IGF-I induced a nearly 3 -fold transient increase in the $\mathrm{IP}_{3}$ mass. This increase was initially fast with a peak that reached a maximum $15 \mathrm{~s}$ after stimulus. A similar result was obtained when the experiment was performed in the absence of extracellular $\mathrm{Ca}^{2+}$ (Fig. 4C, inset). The effect of IGF-I on the $\mathrm{IP}_{3}$ mass increase was dependent on IGF-I concentration (Fig. 3D).
Effects of insulin on intracellular calcium in myotubes

Insulin effects on intracellular $\mathrm{Ca}^{2+}$ signals were tested. Stimulation of myotubes with $50 \mathrm{nM}$ insulin resulted in a mean fluorescence increase in $77.7 \%$ of cells tested (28 of 36 from 18 different cultures) (Fig. 5A). Insulin response was somehow variable in intensity, ranging from 50 to 200 times the basal value of fluorescence (Fig. 5A-D). The kinetics of this response was different to that of IGF-I; insulin-induced $\mathrm{Ca}^{2+}$ increase was faster, reaching a peak at $2 \mathrm{~s}$ and returning to basal value $10 \mathrm{~s}$ after insulin addition. In $43.6 \%$ of myotubes, two to four oscillations were seen around $40 \mathrm{~s}$ after stimulus (Figs $5 \mathrm{C}$ and $7 \mathrm{~B}$ ). The involvement of genistein-sensitive tyrosine kinase, related to insulin receptor, was evaluated. Myotubes were stimulated with insulin in the presence or absence of 

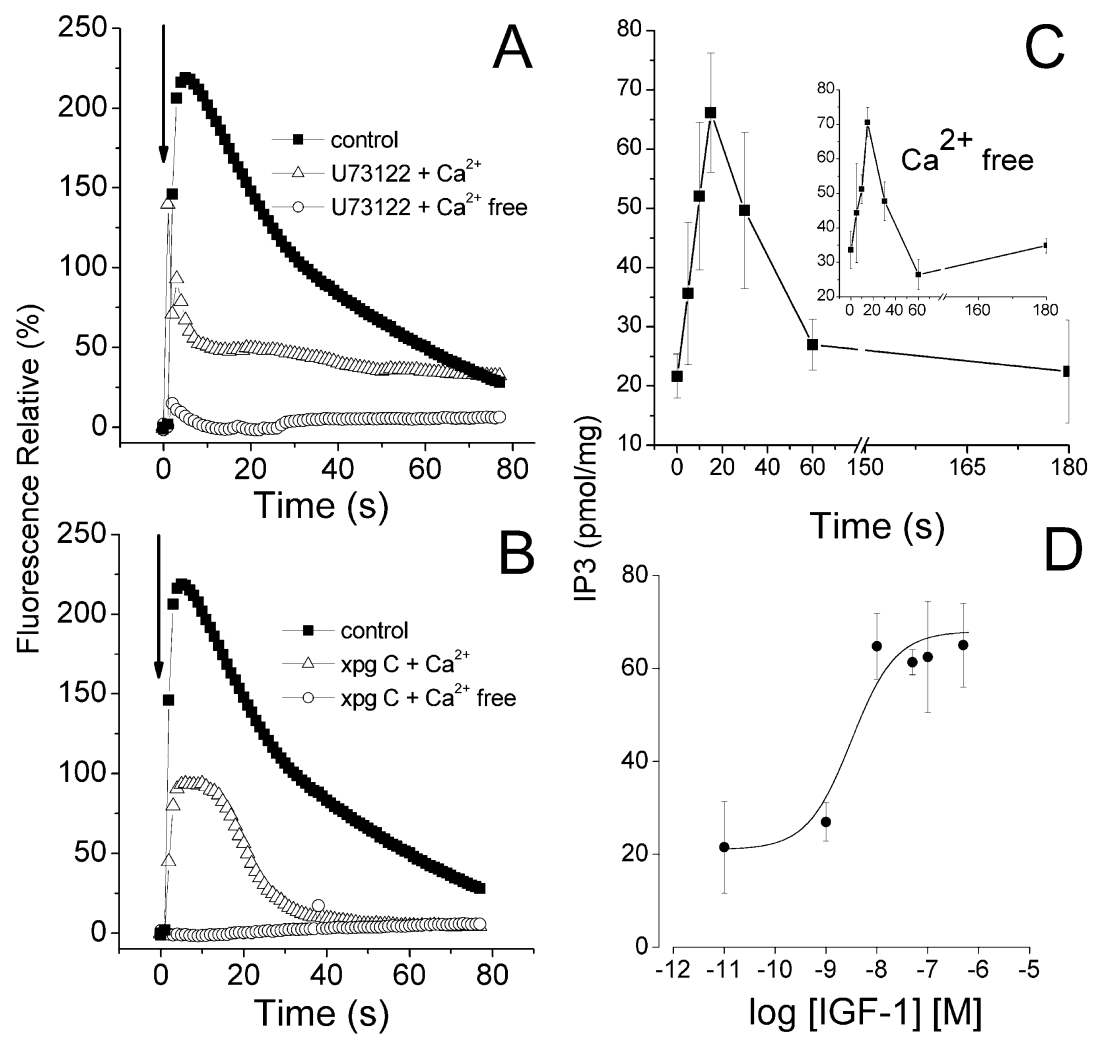

Figure 4 Involvement of $\mathrm{IP}_{3}$ pathway in the IGF-I-triggered calcium increase. Effect of $10 \mu \mathrm{M}$ U73122 (A) and $5 \mu \mathrm{M}$ xestospongin $\mathrm{C}(\mathrm{B}$; xpg $\mathrm{C}$ ) on fluorescence changes elicited by $10 \mathrm{nM}$ IGF-I in myotubes. Inhibitors were tested in both calcium and calcium-free medium $(n=12$ for each condition). (C) IP 3 production in myotubes at different times, after stimulation with IGF-I. Total IP $\mathrm{P}_{3}$ mass was measured as described in Materials and Methods. Inset, measurement of $I P_{3}$ production in a calcium-free medium. (D) IP $\mathrm{P}_{3}$ increase depends on IGF-I concentration, the measurement was performed $15 \mathrm{~s}$ after hormone addition (the $\mathrm{IP}_{3}$ mass corresponds to the mean \pm S.D. of three experiments performed in triplicate).

genistein. Genistein blocked the insulin-induced $\mathrm{Ca}^{2+}$ increase (Fig. 5B), indicating tyrosine kinase receptor participation $(n=12)$. We examined the effects of various inhibitors on the $\mathrm{Ca}^{2+}$ signal induced by insulin. Unlike the signal produced by IGF-I, the insulin-induced intracellular $\mathrm{Ca}^{2+}$ increase was almost completely blocked in either $\mathrm{Ca}^{2+}$-free medium (Fig. 5C) or in medium containing $20 \mu \mathrm{M}$ nifedipine (Fig. 5D). The use of $20 \mu \mathrm{M}$ ryanodine (Fig. 5D) also completely eliminated the fast $\mathrm{Ca}^{2+}$ response. On the other hand, inhibitors of the $\mathrm{IP}_{3}$ pathway, $\mathrm{U} 73122$ (Fig. $5 \mathrm{E}$ ), xestospongin $\mathrm{C}$ or 2-aminoethoxydiphenyl borate (2-APB) (data not shown) did not produce any inhibitory effect on the $\mathrm{Ca}^{2+}$ increases evoked by insulin. Accordingly, myotubes treated with insulin exhibit no detectable modifications of intracellular $\mathrm{IP}_{3}$ mass (data not shown).

\section{Effects of IGF-I and insulin in different skeletal muscle cells}

To further explore the role of DHPRs and RyRs on the IGF-I- and insulin-mediated $\mathrm{Ca}^{2+}$ signals, we worked with skeletal muscle cell lines. A normal skeletal muscle cell line (NLT) was used as control; a dysgenic skeletal muscle cell line (GLT), which does not express the a1-subunit from DHPRs, and myotubes from the dyspedic skeletal muscle cell line (1B5), which lacks RyRs, were also used. In all three muscle cell lines, both IGF-I receptor as well as insulin receptor were present (Fig. 6E). Fluorescence increased in NLT cells in response to IGF-I (Fig. 6A). In GLT myotubes, the fluorescence increase was $29 \pm 6 \%$ less than in NLT cells and the kinetics of the signal appear to be different; the fluorescence peak value was reached at $15 \pm 6 \mathrm{~s} \quad(n=9)$ in NLT cells and at $20 \pm 7 \cdot 5 \mathrm{~s}(n=10)$ in GLT cells. In transfected GLT $\alpha 1$ cells, IGF-I-induced $\mathrm{Ca}^{2+}$ increases were similar both in kinetics and magnitude to NLT cells (Fig. 6A; peak value was reached at $14 \pm 3.6 \mathrm{~s} ; n=6)$. Consistent with the signal dependence on RyRs, in dyspedic myotubes (1B5), the fast component of the calcium signal in response to IGF-I was not present (Fig. 6B; $n=14$ ). However, a slow increase in fluorescence was evident after hormone addition (Fig. 6B). Together these results suggest the 

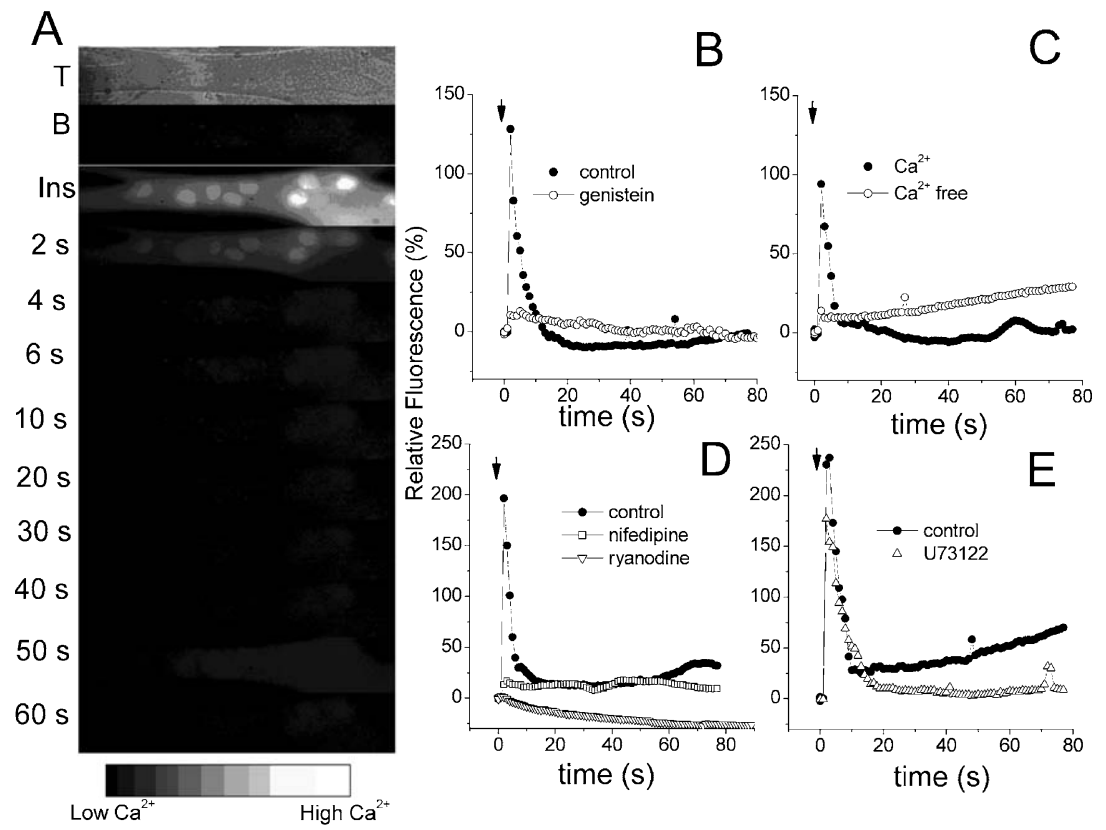

Figure 5 Insulin produces an intracellular calcium increase. (A) Fluorescence changes elicited by $50 \mathrm{nM}$ insulin; series of fluorescence images acquired every $5 \mathrm{~s}$. Fast and transient $(<2 \mathrm{~s})$ calcium increase was produced. $\mathrm{T}$, transmitted image (bright field); B, basal fluorescence. Insulin was added at the time indicated by Ins $(n=28)$. (B) Kinetics of the fluorescence increase produced by insulin, the moment when insulin was added is indicated by the arrow, this response was inhibited by pre-incubation with $100 \mu \mathrm{M}$ genistein as indicated $(n=12)$. (C) Insulin failed to increase fluorescence in a $\mathrm{Ca}^{2+}$-free medium. (D) After pre-incubation with either $20 \mu \mathrm{M}$ nifedipine or $20 \mu \mathrm{M}$ ryanodine, insulin failed to elicit a response. (E) Effect of insulin with or without $10 \mu \mathrm{M} U 73122(n=3)$. Unless indicated, all experiments were performed in $\mathrm{Ca}^{2+}$ medium.

participation of both DHPR and RyR in the fast phase of IGF-I-induced signal; however the main part of this signal is related to $\mathrm{IP}_{3}$-mediated $\mathrm{Ca}^{2+}$ increase.

When insulin-induced $\mathrm{Ca}^{2+}$ increases were evaluated in these muscle cell lines, $72 \%$ (18 out of 25 cells, from 9 different cultures) of NLT cells responded. Insulin produced a fast and transient $\mathrm{Ca}^{2+}$ increase (Fig. 6C), with up-rise kinetics similar to those of primary myotubes, but generally displaying a slower falling face. In GLT cells the fast part of the $\mathrm{Ca}^{2+}$ rise evoked by insulin was either absent (10 out of 14 experiments) or greatly reduced (4 out of 14 experiments) (Fig. 6C). In GLT $\alpha 1$ cells, the insulin response was partly recovered, a fast rise was clearly present (Fig. 6C, $n=7$ ) but the signal was long lasting. When insulin was added to $1 \mathrm{~B} 5$ cells (Fig. $6 \mathrm{D}, n=12$ ) the fast component observed in NLT cells and primary myotubes was either absent or very small; normally, a sustained low level of fluorescence was seen.

\section{Effect of PTX on IGF-I-induced calcium release}

To determine whether a G-protein was involved in either IGF-I- or insulin-induced $\mathrm{Ca}^{2+}$ signals, we used PTX and GDP $\beta S$, a non-hydrolysable GDP analog, before stimulating with hormones in primary myotubes. The $\mathrm{Ca}^{2+}$ signal elicited by IGF-I was slowed down in the presence of $1 \mu \mathrm{g} / \mathrm{ml}$ PTX. The maximum value of fluorescence was reached $16 \pm 5 \mathrm{~s}$ after stimulus $(n=9)$, nevertheless the magnitude of the signal was not significantly altered (Fig. 7A). The same effect was observed with GDP $\beta S$ in which the peak value was reached after $15 \pm 6 \mathrm{~s}(n=8)$. The kinetics of this response, observed with both inhibitors, was similar to that in the presence of either nifedipine or ryanodine. In all of these cases the peak value of fluorescence was reached around $15 \mathrm{~s}$ after stimulus. By contrast, insulin-induced intracellular $\mathrm{Ca}^{2+}$ increases were almost completely blocked in the presence of either PTX or GDP $\beta S$ ( $n=8$ and $n=5$ respectively; Fig. 7B). These data suggest that a G-protein is involved in the $\mathrm{Ca}^{2+}$ response to insulin in myotubes.

\section{Discussion}

In this study we have demonstrated that both IGF-I and insulin produce fast and transient $\mathrm{Ca}^{2+}$ increases in myotubes. We routinely used 1-10 nM IGF-I, this concentration corresponding to $7 \cdot 6-76 \mathrm{ng} / \mathrm{ml}$, a value higher 

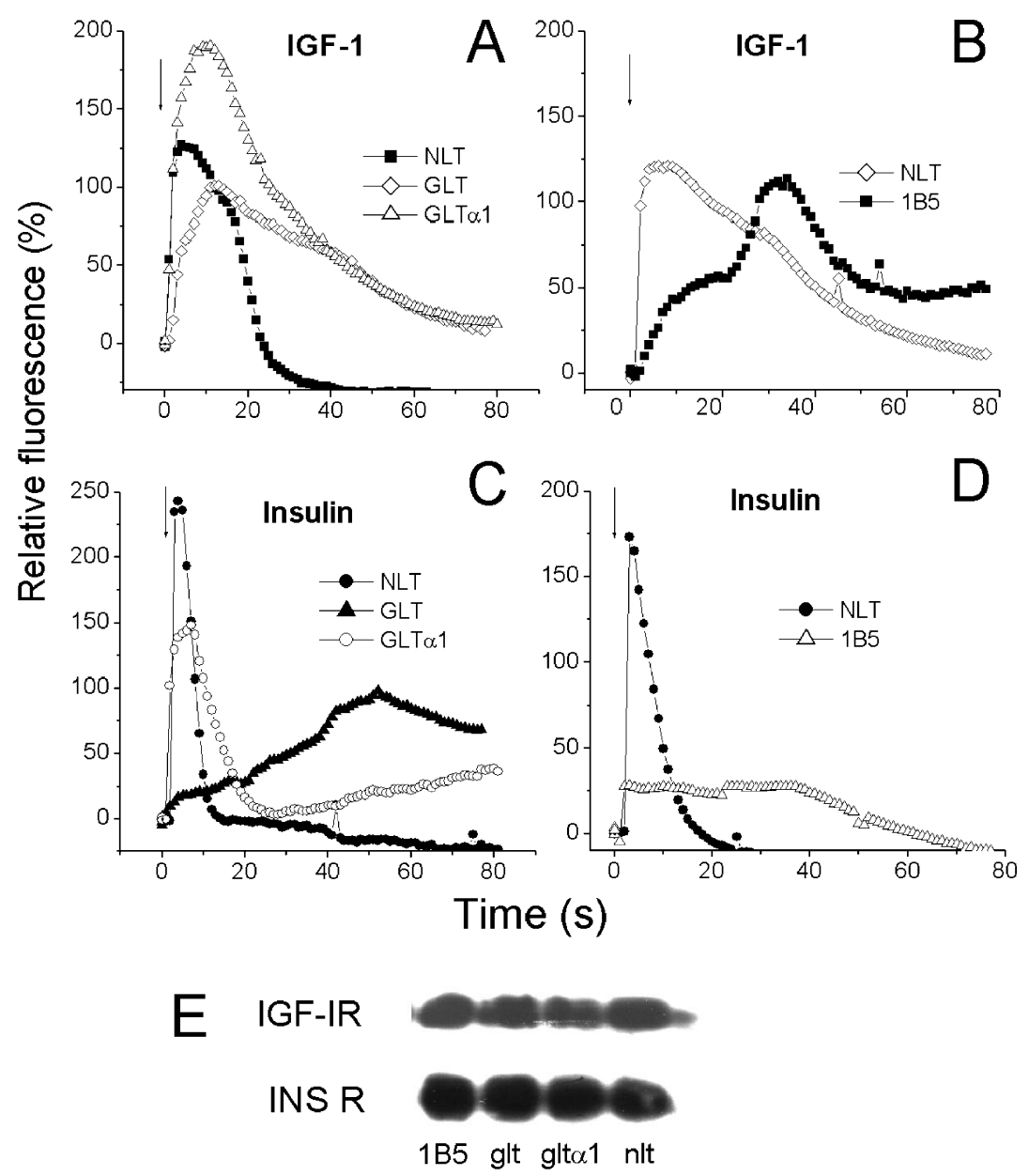

Figure 6 IGF-I and insulin effects in dysgenic and dyspedic cells. (A) Kinetics of $\mathrm{Ca}^{2+}$ changes elicited by 10 nM IGF-I both in a normal myoblast cell line (NLT) and in dysgenic cells (GLT). In GLT cells, the fast component is reduced and was partly recovered in GLT cells transfected with the $\alpha 1$-subunit (GLT $\alpha 1$ ) of DHPR. (B) Effect of IGF-I on dyspedic (1B5) cells. The fluorescence increase was different to that of NLT cells; only a slow $\mathrm{Ca}^{2+}$ increase was observed. (C) Calcium increase elicited by insulin in NLT cells, GLT cells and GLT 1 cells. Note that GLT cells did not show a fast fluorescence increase with insulin, but the transfected cell line presented the fast component of the signal. (D) Effect of $50 \mathrm{nM}$ insulin on calcium increase in both NLT cells and 1B5 cells, the fluorescence increase was minimal in dyspedic cells. (E) Western blot analysis of IGF-IR and IR. Cell lysates from all three cell lines presented both IGF-I and insulin receptors.

than that reported by Le Roith et al. (2001) in rodent blood $(5 \cdot 05 \pm 1 \cdot 2 \mathrm{ng} / \mathrm{ml})$. Nevertheless, the local concentration of IGF-I could be higher, since it can emulate the action of mechano growth factor on the myocyte. This is an autocrine/paracrine IGF-I splice variant, detectable upon both mechanical and electrical stimulation (McKoy et al. 1999). Normal plasma levels of insulin in rodents are of the order of 0.5-2 ng/ml (Morgan et al. 1963). The insulin concentrations we are using are higher than physiological plasma levels and we cannot ascertain whether the final concentrations we used are of physiological significance, although they are in the lower range of those reported for in vitro studies in the literature (Imamura et al. 1999, Dalle et al. 2001); in any case, it is interesting to study the possible cross-reactivity of IGF-I receptors for insulin at high concentrations.

IGF-I-induced intracellular $\mathrm{Ca}^{2+}$ increase is complex, involving at least two processes. The main part of the $\mathrm{Ca}^{2+}$ signal appears to be due to $\mathrm{Ca}^{2+}$ release from intracellular stores through $\mathrm{IP}_{3}$ receptors. An early component appears to be sensitive to both dihydropyridines and ryanodine. On the other hand, the insulin response was completely dependent on both extracellular $\mathrm{Ca}^{2+}$ and on RyRs, resembling the first phase of the response to IGF-I. 


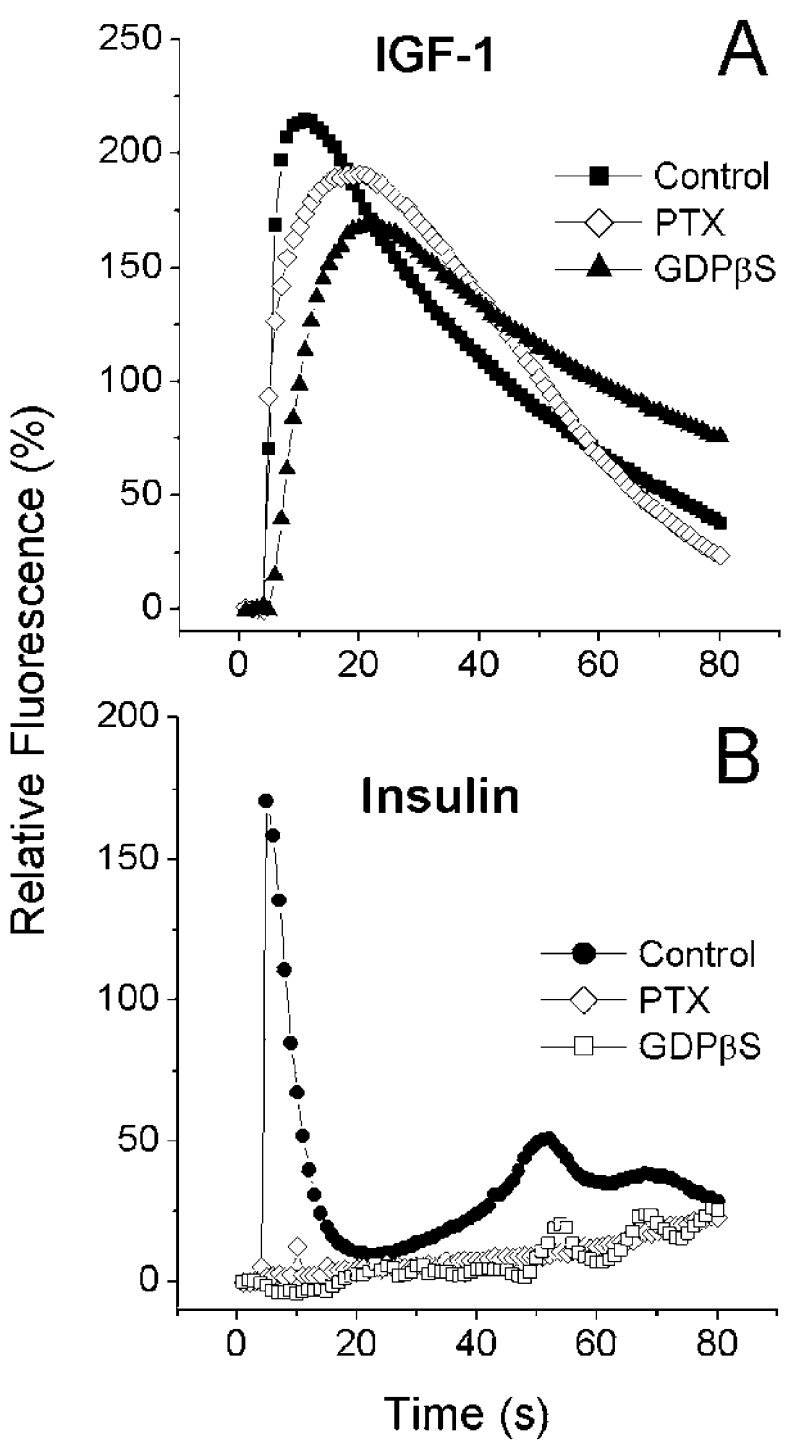

Figure 7 G-protein inhibitors partly inhibit the IGF-I effect and totally block insulin-induced calcium increase. (A) Cells were either pre-incubated for $8 \mathrm{~h}$ with $1 \mu \mathrm{g} / \mathrm{ml}$ PTX or permeabilized and incubated for 5 min with $100 \mathrm{nM}$ GDP $\beta S$. Both inhibitors produced a delayed calcium signal when incubated with IGF-I. (B) Similar treatment with $1 \mu \mathrm{g} / \mathrm{ml}$ PTX and $100 \mathrm{nM}$ GDP $\beta S$ totally abolished the fast signal induced by insulin in myotubes. Control for permeabilized cells (not shown) was similar to the untreated control cells.

IGF-I is a factor required for myogenic differentiation and subsequent growth and hypertrophy of myofibers (Coleman et al. 1995, Musaro et al. 1999). These effects are triggered by activation of well-known signal transduction pathways such as MAPK, PI3K and calcineurin (Coolican et al. 1997, Semsarian et al. 1999). The mechanisms of activation for these pathways are not totally clear. $\mathrm{Ca}^{2+}$ increase has been postulated as a possible mediator in these signals (Poiraudeau et al. 1997; Semsarian et al. 1999). If we analyze the $\mathrm{Ca}^{2+}$ response elicited by IGF-I and we separate the signal into two components: an early, fast $\mathrm{Ca}^{2+}$ transient remains after we use $\mathrm{IP}_{3}$ pathway inhibitors (xestospongin $\mathrm{C}$ and U73122); on the other hand, a delayed response can be seen in isolation after we blocked the faster component using nifedipine, ryanodine, or G-protein inhibitors. The peak value of fluorescence from the second response was reached at times compatible with the maximum value of $\mathrm{IP}_{3}$ production elicited by IGF-I. It is possible then to consider that the actual response of IGF-I receptor to its ligand is relatively slow and that it is mediated by $\mathrm{IP}_{3}$. IGF-I-induced $\mathrm{IP}_{3}$ production has been shown in rat cardiac myocytes (Guse et al. 1992) and porcine thyroid cells (Takasu et al. 1989). In $\mathrm{C}_{2} \mathrm{C}_{12}$ myotubes in which IGF-I production was over-expressed, a fast calcium signal has been recently described involving the participation of store-operated $\mathrm{Ca}^{2+}$ channels (SOCCs) (Ju et al. 2003). In our work, we show that IGF-I produced a $\mathrm{Ca}^{2+}$ release from internal stores through $\mathrm{IP}_{3} \mathrm{R}$ activation; it is possible that when $\mathrm{IP}_{3}$-dependent $\mathrm{Ca}^{2+}$ stores are depleted, SOCC activation will occur.

The kinetics of the fluorescence changes produced by insulin were different from those changes produced by IGF-I. Calcium increase was fast and transient, returning to basal values in a few seconds. Moreover, the response was completely dependent on extracellular $\mathrm{Ca}^{2+}$. A recent study on fresh mouse muscle fibers showed that insulin increased the calcium concentration in the cytoplasm located near the plasma membrane (Bruton et al. 2001). These results suggest that insulin triggers an entry of calcium from outside the cell rather than a release from the sarcoplasmic reticulum (SR). The signal triggered by insulin in our model is explained by calcium release from SR, through RyRs. The kinetics of this signal is similar to the calcium transient involved in skeletal muscle contraction. In adult muscle, either exercise or insulin induces translocation of GLUT-4 to the membrane (Ryder et al. 2001). It is possible that the calcium signal we described could be involved in this type of insulin effect.

Since both IGF-I and insulin receptors share a similar structure, it is plausible that IGF-I could also interact with insulin receptors. Moreover a hybrid receptor to both IGF-I and insulin has been reported to exist (Pandini et al. 2002). The $\mathrm{Ca}^{2+}$ increase produced via insulin receptors could represent the first part of the response to IGF-I. Also the signal induced by insulin in NLT cells (Fig. 6C) shows prolonged kinetics that may be attributable to an effect of insulin on either IGF-I receptors or hybrid receptors. When we used either nifedipine or ryanodine, both blockers of the insulin receptor-associated signal, they turned the IGF-I-induced $\mathrm{Ca}^{2+}$ signal into a single slow $\mathrm{Ca}^{2+}$ rise. The fact that the inhibitory effect of ryanodine was larger than that of nifedipine can be explained by intracellular $\mathrm{Ca}^{2+}$ depletion mediated by ryanodine, impairing the $\mathrm{IP}_{3}$-induced calcium release. 
In order to confirm the role of both DHPRs and RyRs on IGF-I- and insulin-regulated signals, we tested different muscle cell lines that express both IGF-I and insulin receptors. GLT cells do not express the $\alpha 1$-subunit of the DHPR; insulin elicited no $\mathrm{Ca}^{2+}$ signals in these cells, but upon transfection with the $\alpha 1-\mathrm{DHPR}$-subunit, the $\mathrm{Ca}^{2+}$ signal was recovered (Fig. 6D). The fact that a dihydropyridine such as nifedipine blocks the insulin-induced calcium signal does not necessarily mean that calcium influx is needed for this signal. The DHPRs have been shown to mediate excitation-contraction coupling in the absence of calcium influx (Dulhunty et al. 2002). Moreover, in addition to antagonizing calcium flux, the dihydropyridines can act as an immobilizing part of the charge movement of the $\alpha 1$-subunit of DHPRs, resulting in a reduction of intracellular calcium (Lamb 1986). When we used a cell line that lacks expression of RyRs (1B5), no significant $\mathrm{Ca}^{2+}$ increase upon insulin addition was observed. Both GLT and 1B5 cells do respond to IGF-I stimulation, indicating that the IGF-I receptor acts through a pathway that is essentially independent of both Ry and DHP receptors.

The effect of IGF-I on intracellular $\mathrm{Ca}^{2+}$ increase in myotubes is not blocked by PTX, but the kinetics of the response was slower than control, suggesting that a G-protein modulates the first part of the signal. We have demonstrated that the insulin receptor mediates a G-protein-dependent signal, because both PTX and GDP $\beta S$ completely block insulin-induced calcium release. This evidence again favors the idea that the first part of the signal is dependent on insulin receptors.

In skeletal muscle cells, DHPRs are linked to RyRs, to produce a fast calcium release signal to trigger excitationcontraction coupling. Although no G-protein has been shown to be involved in this mechanism (Lamb \& Stephenson 1991), it might well be that a G-proteincomponent connects insulin receptors with DHPRs. It has been reported in the literature that $G \beta \gamma$ can modulate a DHPR channel in rat vein myocytes (Viard et al. 1999), producing calcium entry. It has also been reported that insulin augments the inward calcium current and that this effect can be abolished by PTX and GDPßS (Nie et al. 1998).

As mentioned above, it is possible that IGF-I also interacts with insulin receptors; we cannot rule out that IGF-I receptor could also mediate DHPR regulation. Delbono et al. (1997) have shown that IGF-I facilitates skeletal muscle DHPR activity, producing opening of this $\mathrm{Ca}^{2+}$ channel. It is possible then that the early part of the calcium signal induced by IGF-I could be due to calcium release from RyR after IGF-I activation of DHPR.

We propose an alternative model which explains our results (Fig. 8). IGF-I can interact with both insulin receptor (producing a fast calcium signal component) and its own receptor (producing a slow calcium signal component); likewise, insulin can interact with both receptors

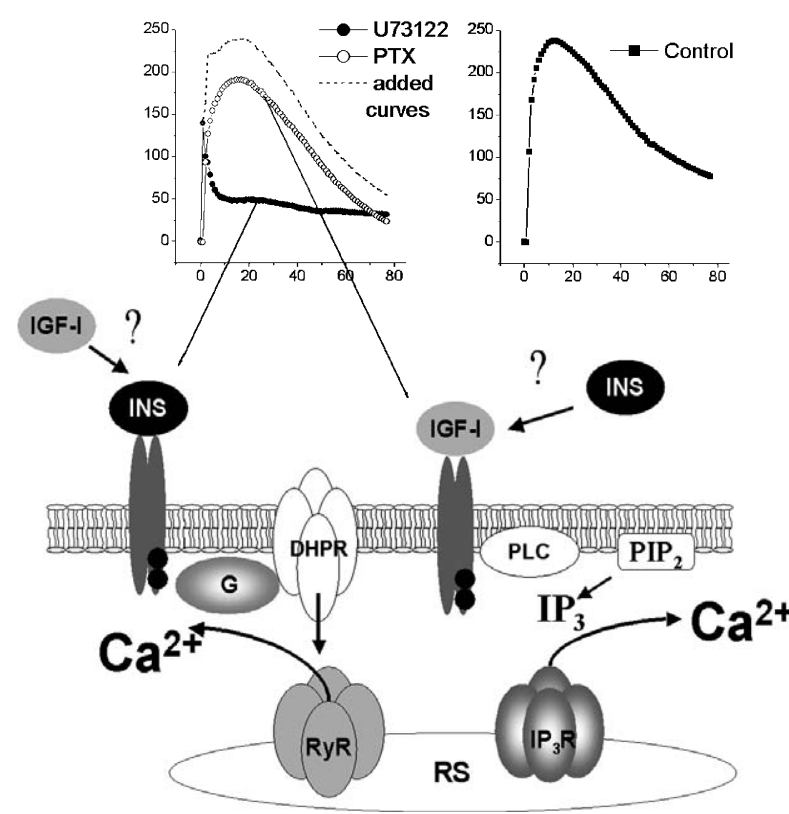

Figure 8 Simplest model proposed to explain calcium increases elicited by both IGF-I and insulin. The scheme shows that IGF-I binds to IGF-I receptors and triggers PLC activation. $\mathrm{IP}_{3}$ is produced and calcium is released through $\mathrm{IP}_{3}$ receptors $\left(\mathrm{IP}_{3} \mathrm{Rs}\right)$. This mechanism is probably responsible for the slow component of the IGF-I calcium response in myotubes. The IGF-I response in the absence of inhibitors probably represents its action on both receptors. The graph (upper-left panel) shows a representative experiment in the presence of an inhibitor of PLC (U73122) (O). This curve probably represents the effect of IGF-I acting on insulin receptors. On the other hand, insulin binds to its receptor and triggers an interaction between DHPRs and RyRs. This interaction produces calcium release through the latter. A G-protein mediates the interaction between insulin receptors and DHPRs. The curve seen in the presence of U73122 was probably produced through this mechanism by IGF-I acting on insulin receptors. The IGF-I-induced signal in the presence of PTX (upper-left panel, O) probably represents the effect of IGF-I acting on its receptor alone. Addition of the two curves (dashed line), one with an inhibitor of the first part of the signal (PTX) and the other with an inhibitor of the second part of the signal (U73122), gives a curve not unlike those seen after IGF-I addition alone (upper-right panel and Fig. 1B).

(producing both fast and slow signals), both molecules having higher affinity for their own receptor. When activated, the IGF-I receptor will in turn activate PLC to produce $\mathrm{IP}_{3}$, which will release calcium from $\mathrm{SR}$. On the other hand, when activated, the insulin receptor will interact with a G-protein and this will result in activation of DHPR, which in turn will activate RyRs, producing $\mathrm{Ca}^{2+}$ release. In fact, if we add the fast component of the IGF-I-induced signal obtained in the presence of U73122 to the slow component of this signal, obtained in the presence of PTX, the curve representing the sum of these two components does not differ from the signal evoked by IGF-I alone (Fig. 8). The first part of the curve obtained in 
the presence of U73122 is kinetically similar and could be replaced by the signal induced by insulin.

Our simple model (Fig. 8) proposes that each stimulus will activate different signal transduction pathways, both involving $\mathrm{Ca}^{2+}$ increase in skeletal muscle cells. Both pathways are dependent on tyrosine kinase activity, but one of them (insulin) depends on a PTX-sensitive G-protein and the other one (IGF-I) is mediated by PLC activation. A more complex explanation would be for IGF-I receptor to trigger responses, i.e calcium release, by an increase of $\mathrm{IP}_{3}$ production and calcium release by activation of RyR. The sum of both mechanisms could be the final curve shown for IGF-I. This suggestion is supported by a dual mechanism for calcium increase that has been proposed in cultured articular chondrocytes (Poiraudeau et al. 1997).

In previous studies we have demonstrated the presence of different $\mathrm{IP}_{3}$ receptor isoforms in skeletal muscle cells and we have explained the function of these receptors both in calcium release and regulation of gene expression (Powell et al. 2001, Carrasco et al. 2003). It is likely that calcium signals elicited by both insulin and IGF-I would be involved in regulation of gene expression as well. IGF-I induced calcium signals due to calcium release and related to activation of transcription factors in cardiomyocytes (Ibarra et al. 2004). In a similar cell model, myosin light chain 2 and troponin I expression was up-regulated by IGF-I and this response was calcium dependent (Huang et al. 2002). In skeletal myoblasts, IGF-I activates signaling pathways that increase the expression of muscle-specific genes such as $\alpha$-actin, in a $\mathrm{Ca}^{2+}$-dependent manner (Spangenburg et al. 2004). Other studies have shown that external calcium is required for markers of skeletal myoblast differentiation expression in $\mathrm{C}_{2} \mathrm{C}_{12}$ cells (Porter et al. 2002).

Since we are using partly differentiated myotubes from neonatal rats, we cannot ascertain whether the signal we described participates in the differentiation process or whether it also plays a role in adult muscle tissue. Further studies, using a developmental approach will be needed to address this issue.

The fact that IGF-I receptors and insulin receptors appear to elicit calcium signals that differ both in kinetics and intracellular release mechanisms could provide future clues on how calcium signals can differentially regulate gene expression in response to different hormones.

\section{Acknowledgements}

We thank José Luis Liberona for help in the $\mathrm{IP}_{3}$ mass measurements, Dr Sergio Lavandero for the gift of purified IGF-I, Germán Iñiguez for anti-IGF-IR and anti-IR antibodies and Mónica Silva for the muscle cell cultures.

\section{Funding}

This work was financed by Fondo Nacional de Investigación Avanzada en Areas Prioritarias (15010006). There is no conflict of interest that would prejudice the impartiality of this research.

\section{References}

Adams GR 2002 Autocrine/paracrine IGF-I and skeletal muscle adaptation. Journal of Applied Physiology 93 1159-1167.

Araya R, Liberona JL, Cardenas J, Riveros N, Estrada M, Powell JA, Carrasco MA \& Jaimovich E 2003 Dihydropyridine receptors as voltage sensors for a depolarization-evoked, $\mathrm{IP}_{3} \mathrm{R}$-mediated, slow calcium signal in skeletal muscle cells. Journal of General Physiology $1213-16$.

Berridge MJ 1995 Inositol trisphosphate and calcium signaling. Annals of the New York Academy of Sciences 766 31-43.

Blakesley VA, Scrimgeour A, Esposito D \& Le Roith D 1996 Signaling via the insulin-like growth factor-I receptor: does it differ from insulin receptor signaling? Cytokine Growth Factor Review $\mathbf{7}$ 153-159.

Blum G, Gazit A \& Levitzki A 2000 Substrate competitive inhibitors of IGF-1 receptor kinase. Biochemistry 39 15705-15712.

Bredt DS, Mourey RJ \& Snyder SH 1989 A simple, sensitive, and specific radioreceptor assay for inositol 1,4,5-trisphosphate in biological tissues. Biochemical and Biophysical Research Communications 159 976-982.

Bruton JD, Katz A \& Westerblad H 2001 The role of $\mathrm{Ca}^{2+}$ and calmodulin in insulin signalling in mammalian skeletal muscle. Acta Physiologica Scandinavica 171 259-265.

Carrasco MA, Riveros N, Rios J, Muller M, Torres F, Pineda J, Lantadilla S \& Jaimovich E 2003 Depolarization-induced slow calcium transients activate early genes in skeletal muscle cells. American Journal of Physiology and Cell Physiology 284 C1438-C1447.

Coleman ME, DeMayo F, Yin KC, Lee HM, Geske R, Montgomery C \& Schwartz RJ 1995 Myogenic vector expression of insulin-like growth factor I stimulates muscle cell differentiation and myofiber hypertrophy in transgenic mice. Journal of Biological Chemistry 270 12109-12116.

Coolican SA, Samuel DS, Ewton DZ, McWade FJ \& Florini JR 1997 The mitogenic and myogenic actions of insulin-like growth factors utilize distinct signaling pathways. Journal of Biological Chemistry 272 6653-6662.

Crown AL, He XL, Holly JM, Lightman SL \& Stewart CE 2000 Characterization of the IGF system in a primary adult human skeletal muscle cell model, and comparison of the effects of insulin and IGF-I on protein metabolism. Journal of Endocrinology 167 403-415.

Dalle S, Ricketts W, Imamura T, Vollenweider P \& Olefsky JM 2001 Insulin and insulin-like growth factor I receptors utilize different G protein signaling components. Journal of Biological Chemistry 276 15688-15695.

Delbono O, Renganathan M \& Messi ML 1997 Regulation of mouse skeletal muscle L-type $\mathrm{Ca}^{2+}$ channel by activation of the insulin-like growth factor-1 receptor. Journal of Neuroscience 17 6918-6928.

Dulhunty AF, Haarmann CS, Green D, Laver DR, Board PG \& Casarotto MG 2002 Interactions between dihydropyridine receptors and ryanodine receptors in striated muscle. Progress in Biophysics and Molecular Biology 79 45-75.

Estrada M, Liberona JL, Miranda M \& Jaimovich E 2000 Aldosteroneand testosterone-mediated intracellular calcium response in skeletal muscle cell culture. American Journal of Physiology, Endocrinology and Metabolism 279 E132-E139. 
Estrada M, Espinosa A, Muller M \& Jaimovich E 2003 Testosterone stimulates intracellular calcium release and mitogen-activated protein kinases via a $G$ protein-coupled receptor in skeletal muscle cells. Endocrinology 144 3586-3597.

Foskett JK, Roifman CM \& Wong D 1991 Activation of calcium oscillations by thapsigargin in parotid acinar cells. Journal of Biological Chemistry 266 2778-2782.

Guse AH, Kiess W, Funk B, Kessler U, Berg I \& Gercken G 1992 Identification and characterization of insulin-like growth factor receptors on adult rat cardiac myocytes: Linkage to inositol 1,4,5-trisphosphate formation. Endrocrinology 130 145-151.

Hong F, Moon Ka, Kim SS, Kim YS, Choi YK, Bae YS, Suh PG, Ryu SH, Choi EJ, Ha J \& Kim SS 2001 Role of phospholipase $\mathrm{C}$-gamma1 in insulin-like growth factor I-induced muscle differentiation of $\mathrm{H} 9 \mathrm{c} 2$ cardiac myoblasts. Biochemical and Biophysical Research Communications 282 816-822.

Huang CY, Hao LY \& Buetow DE 2002 Insulin-like growth factor-induced hypertrophy of cultured adult rat cardiomyocytes is L-type calcium-channel-dependent. Molecular and Cellular Biochemistry 231 51-59.

Ibarra C, Estrada M, Carrasco L, Chiong M, Liberona JL, Cardenas C, Diaz-Araya G, Jaimovich E \& Lavandero S 2004 Insulin-like growth factor-1 induces an inositol 1,4,5-trisphosphate-dependent increase in nuclear and cytosolic calcium in cultured rat cardiac myocytes. Journal of Biological Chemistry 279 7554-7565.

Imamura T, Vollenweider P, Egawa K, Clodi M, Ishibashi K, Nakashima N, Ugi S, Adams JW, Brown JH \& Olefsky JM 1999 $\mathrm{G}$ alpha-q/11 protein plays a key role in insulin-induced glucose transport in 3T3-L1 adipocytes. Molecular and Cellular Biology 19 6765-6774.

Jaimovich E \& Rojas E 1994 Intracellular Ca2+ transients induced by high external $\mathrm{K}+$ and tetracaine in cultured rat myotubes. Cell Calcium 15 356-368.

Jaimovich E, Reyes R, Liberona JL \& Powell JA 2000 IP(3) receptors, $\mathrm{IP}(3)$ transients, and nucleus-associated $\mathrm{Ca}(2+)$ signals in cultured skeletal muscle. American Journal of Physiology and Cell Physiology 278 C998-C1010.

Ju YK, Wu MJ, Chaulet H, Marciniec T, Graham RM \& Allen DG 2003 IGF-1 enhances a store-operated Ca2+ channel in skeletal muscle myoblasts: involvement of a CD20-like protein. Journal of Cellular Physiology 197 53-60.

Kaburagi Y, Yamauchi T, Yamamoto-Honda R, Ueki K, Tobe K, Akanuma Y, Yazaki Y \& Kadowaki T 1999 The mechanism of insulin-induced signal transduction mediated by the insulin receptor substrate family. Endocrine Journal 46 25-34.

Kanoh Y, Ishizuka T, Morita H, Ishizawa M, Miura A, Kajita K, Kimura M, Suzuki T, Sakuma H \& Yasuda K 2002 Effect of pertussis toxin on insulin-induced signal transduction in rat adipocytes and soleus muscles. Cell Signal 12 223-232.

Kimball SR, Farrell PA \& Jefferson LS 2002 Invited Review: Role of insulin in translational control of protein synthesis in skeletal muscle by amino acids or exercise. Journal of Applied Physiology $\mathbf{9 3}$ $1168-1180$

Kuemmerle JF \& Murthy KS 2001 Coupling of the insulin-like growth factor-I receptor tyrosine kinase to $G_{i 2}$ in human intestinal smooth muscle: Gbetagamma-dependent mitogen-activated protein kinase activation and growth. Journal of Biological Chemistry 276 7187-7194.

Lamb GD 1986 Components of charge movement in rabbit skeletal muscle: the effect of tetracaine and nifedipine. Journal of Physiology $37685-100$.

Lamb GD \& Stephenson DG 1991 Excitation-contraction coupling in skeletal muscle fibres of rat and toad in the presence of GTP gamma S. Journal of Physiology 444 65-84.

Le Roith D, Scavo L \& Butler A 2001 What is the role of circulating IGF-I? Trends in Endocrinology and Metabolism 12 48-52.
McKoy G, Ashley W, Mander J, Yang SY, Williams N, Russell B \& Goldspink G 1999 Expression of insulin growth factor-1 splice variants and structural genes in rabbit skeletal muscle induced by stretch and stimulation. Journal of Physiology 516 583-592.

Minta A, Kao JP \& Tsien RY 1989 Fluorescent indicators for cytosolic calcium based on rhodamine and fluorescent chromophores. Journal of Biological Chemistry 264 8171-8178.

Moore RA, Nguyen H, Galceran J, Pessah IN \& Allen PD 1998 A transgenic myogenic cell line lacking ryanodine receptor protein for homologous expression studies: reconstitution of Ry1R protein and function. Journal of Cell Biology 140 843-851.

Morgan CR \& Lazarow A 1963 Immunoassay of insulin: Two antibody system. Plasma insulin levels in normal, subdiabetic rat. Diabetes 12 115-126.

Musaro A, McCullagh KJ, Naya FJ, Olson EN \& Rosenthal N 1999 IGF-1 induces skeletal myocyte hypertrophy through calcineurin in association with GATA-2 and NF-ATc1. Nature 400 581-585.

Nie L, Kanzaki M, Shibata H \& Kojima I 1998 Activation of calcium-permeable cation channel by insulin in Chinese hamster ovary cells expressing human insulin receptors. Endocrinology 139 179-188.

Pandini G, Frasca F, Mineo R, Sciacca L, Vigneri R \& Belfiore A 2002 Insulin/insulin-like growth factor I hybrid receptors have different biological characteristics depending on the insulin receptor isoform involved. Journal of Biological Chemistry 277 39684-39695.

Poiraudeau S, Lieberherr M, Kergosie N \& Corvol MT 1997 Different mechanisms are involved in intracellular calcium increase by insulin-like growth factors 1 and 2 in articular chondrocytes: voltage-gated calcium channels, and/or phospholipase C coupled to a pertussis-sensitive G-protein. Journal of Cellular Biochemistry 64 414-422.

Porter GA Jr, Makuck RF \& Rivkees SA 2002 Reduction in intracellular calcium levels inhibits myoblast differentiation. Journal of Biological Chemistry 277 28942-28947.

Powell JA, Petherbridge L \& Flucher BE 1996 Formation of triads without the dihydropyridine receptor subunits in cell lines from dysgenic skeletal muscle. Journal of Cellular Biology 134 375-387.

Powell JA, Carrasco MA, Adams DS, Drouet B, Rios J, Muller M, Estrada M \& Jaimovich E $2001 \mathrm{IP}_{3}$ receptor function and localization in myotubes: an unexplored $\mathrm{Ca}^{2+}$ signaling pathway in skeletal muscle. Journal of Cell Science 114 3673-3683.

Renganathan M, Messi ML, Schwartz R \& Delbono O 1997 Overexpression of hIGF-1 exclusively in skeletal muscle increases the number of dihydropyridine receptors in adult transgenic mice. FEBS Letters 417 13-16.

Ryder JW, Chibalin AV \& Zierath JR 2001 Intracellular mechanisms underlying increases in glucose uptake in response to insulin or exercise in skeletal muscle. Acta Physiologica Scandinavica 171 249-257.

Semsarian C, Wu MJ, Ju YK, Marciniec T, Yeoh T, Allen DG, Harvey RP \& Graham RM 1999 Skeletal muscle hypertrophy is mediated by a $\mathrm{Ca}^{2+}$-dependent calcineurin signalling pathway. Nature 400 576-581.

Solem ML \& Thomas AP 1998 Modulation of cardiac Ca2+ channels by IGF1. Biochemical and Biophysical Research Communications 252 151-155.

Spangenburg EE, Bowles DK \& Booth FW 2004 Insulin-like growth factor-induced transcriptional activity of the skeletal $\alpha$-actin gene is regulated by signaling mechanisms linked to voltage-gated calcium channels during myoblast differentiation. Endocrinology 145 2054-2063.

Takasu N, Takasu M, Komiya I, Nagasawa Y, Asawa T, Shimizu Y \& Yamada T 1989 Insulin-like growth factor I stimulates inositol trisphosphate accumulation, a rise in cytoplasmic free calcium, and proliferation in cultured porcine thyroid cells. Journal of Biological Chemistry 264 18485-18488. 
Tureckova J, Wilson EM, Cappalonga JL \& Rotwein P 2001 Insulin-like growth factor-mediated muscle differentiation. Journal of Biological Chemistry 276 39264-39270.

Viard P, Exner T, Maier U, Mironneau J, Nurnberg B \& Macrez N 1999 Gbetagamma dimers stimulate vascular L-type $\mathrm{Ca}^{2+}$ channels via phosphoinositide 3-kinase. FASEB Journal 13 685-694.
Received 23 April 2004

Accepted 30 April 2004 